\title{
Study on the Teaching Reform of Military Academy Based on the Changes of Combat Capabilities Generation Mode
}

\author{
Li Jian, Ai Chun’an, Zhang Xiaojun, Gao Chen, Wang Xueren \\ Xi'an Research Institute of High technology \\ Xi'an Research Inst. Of Hi-Tech, Hongqing Town, Xi'an, P.R. China \\ e-mail: lijian_206@qq.com
}

\begin{abstract}
This article introduced the background and the character of the changes of combat capabilities generation mode, and suggested that the reform on teaching must be carried on to improve the quality of class teaching and talent training, and exploring the way of improving students' military ability to meet the needs of the changes of combat capabilities generation mode. Around the teaching reform, four issues were discussed, which are military curriculum system, teaching methods, construction of teaching materials and construction of teacher staff. This article is valuable for military academies in the teaching reform with the changes of combat capabilities generation mode.
\end{abstract}

Keywords- combat capabilities generation mode, teaching reform, military quality, the quality of talent training

\section{BACKGROUND AND CHARACTERISTICS OF CHANGES IN THE MODE OF GENERATING COMBAT CAPABILITIES}

Since the late twentieth Century, with the rapid development of information technology as the main hightech group, the fourth science and technology revolution and information technology revolution in human history have began. New military revolution with the information technology as a symbol has become the most prominent feature in the military field, which has brought a revolutionary impact to combat capabilities generation mode.

In 2001 July, the U. S. Defense Department submitted a "network centric warfare" report to Congress, and the theory of combat capabilities generation mode changing to information was put forward for the first time. China in 2006 first proposed the views that in order to adapt to the requirement of building an innovation-oriented country, and achieve the goals of constructing the information army and winning information war, the country must improve military power relying on science and technology, and accelerate to change the mode of combat capabilities generating based on technological progress and innovation.

Among the various factors of combat capabilities generation mode, the human factor is the most active one, the most decisive factor. With the modern science and technology is widely used in the military field, the effection of human factor in the combat capabilities generation mode has not reduced, but more prominent. In the future information battlefield, the modern military talents with highly informational quality will play a decisive role more and more important, so it must from a strategic height to planned construct informational personnel, to make it develop with army building coordinately, to open thinking to advance the development of ideas, to train all kinds of informational talent for the future. Talent is the foundation of army and of winning. Talent advantage determines the future development of army construction "commanding heights ", determines the outcome of future informational war. Military competition is omni-directional; its core is the competition for talent. Our army has always placed great importance on training high-quality military talent in military strategy. There is no question that the most effective means to gain the bridgehead of the future informational war is to train a large number of military talent who can adapt to informational army building and meet the need of information war winning

\section{TEACHING REFORM OF THE MILITARY ACADEMIES BASED ON THE CHANGES OF COMBAT CAPABILITIES GENERATION MODE}

Military academies is the cradle of training the students to be new type of military talents, therefore, its work of training talent plays an important role of fundamentality, overall and guiding. How to make students grow up to be new type of military talents with high quality? It must make the students have all kinds of qualities which should have to become qualified new type military talents. Of all the qualities, the military quality is the most important one which is the cornerstone and the link connecting the other qualities with the demand of future war. In order to improve the military quality of students, the military academies should keep up the pace of the transformation of the combat capabilities generation mode, explore the generation ways of the students' military qualities actively under conditions of informatization, transform from the top-level design breakthrough, take a variety of means to optimize course teaching and make efforts to improve the quality of class teaching and personnel training. The following four issues were discussed, which are teaching course, teaching methods, textbook construction and teaching staff optimization. 


\section{A. Military curriculum system}

To configure military curriculum correctly is the precondition for training military talents with high quality. The military quality which the students should have must be clarified in the personnel training program, and under the direction of the personnel training program, the military training curriculums and its standard should be optimized and established correctly and scientifically to meet the need of the military training. The arrangement of the curriculums in time and space should be reasonable according to the rules of military training. The rationality and practical of the curriculum should be tested and verified by evaluating the students' military quality, and the curriculums should be improved and perfected according to the result of evaluation.

Military curriculum optimization is system engineering, so we must establish a scientific military training curriculum system for training the military quality of the students ${ }^{[1]}$. The so-called military training curriculum system, refers to the structure made up of the military curriculums and of their relationship which subordinate and service for military quality training. For military academy education to solve the problem how to cultivate talents and what kind of talents cultivating, curriculum system construction is the key. Therefore, to construct a scientific and advanced military training curriculum system is one of the core problems in training military quality of students. The military training curriculum system is based on military theory, focused on students' military skills, guided by strengthening their practical ability, and it can make students have all kinds of military qualities, and improve their adaptability for future working. The military training curriculum system is made up of military basic theory courses, military basic knowledge courses and military basic skill courses. It should meet the goal and requirement of talents training, and should be configured according to the character of the military academy, the requirements of future war, and the development trend of military science. The curriculum content should ensure the integrity of the teaching system; also meet the requirements of students' military training, and teaching content must be updated in a timely manner for enhancing the characteristics of the times of curriculum. Only in this way, we can lay a good foundation for training high-quality military talents of a new type.

\section{B. Teaching methods}

The military academies teaching methods are the general term of interrelated and interacting way taken by teachers and students in common activities in order to achieve the purpose of teaching and complete the task of teaching. Teaching methods as a complete process system include both the teaching method of the teachers and the learning method of the students ${ }^{[2]}$. As an important part of cultivating the students' military quality , the optimization of the teaching methods firstly need to build a learner-centered teaching methods and means, by which individualizing depending on the characteristics of the students and developing the learning potential of the students fully. The second is to change the old teaching methods. Some new teaching methods should be used to enhance the effect of classroom teaching such as heuristic, inquiry-based teaching and case teaching. Finally, the teaching time must be planned reasonably. Unlike the traditional way of teaching, teachers need to understand how to make the class "blank". Give a man a fish rather than giving them fish.

\section{Construction of teaching materials [3]}

Teaching material construction is the key of military quality training. Teaching materials construction needs to stand at the height of the information-based war, and aims at implementing the teaching goals, and guided by showing character of teaching. The main teaching materials construction must be pertinence. Construction of teaching material should show stereoscopic, serialization, diversification and professionalization. The so-called stereoscopic is based on the idea of modern education and modern information network technology platform, the traditional paper-based material as the foundation, taking courses as the center, setting different teaching resources integration. The stereoscopic teaching material made up of primary textbooks, reference books, study guides and test library. Specifically it includes teacher guidance, electronic teaching plan, assistant courseware, cases libraries, text materials, online course, question libraries, software tool and instructional environment. The stereoscopic of teaching material is an effective way to make teaching informational and networking, which can integrate education resources, and optimize the allocation of education elements. The socalled serialization is that the teaching materials of different levels should be compiled systematically in accordance with the different requirements of training objectives, training programmes and courses to facilitate the courses of different levels connecting and communicating, form an organic whole, and avoid unnecessary duplication. The diversification of teaching material refers to the material change from uniformity to diversity in form, which puts forward new demands on the connotation and denotation of the material. It needs us to continue do a good job in writing conventional teaching materials, at the same time, develop vigorously teaching materials such as audio-visual and electronic media, and use military networks for multifaceted development. The professionalization of the teaching material refers that to use and development of the teaching materials not only for certain post, but also for post rotation and promotion, and to enhance post adaptability of the students, reflect the professionalization and usability of the teaching material.

\section{Construction of teacher staff}

The teacher as an organizer of teaching activity, a transfer of knowledge and skill and a leader during the 
development of student's physical and mental, plays a leading role in the process of teaching in military academy ${ }^{[4]}$. To build a high-quality team of teachers is the key of improving teaching quality of military courses and enhancing students ' military qualities.

Teacher staff constructing should firstly improve the teachers' awareness of the importance of students' military quality training, and encourage the teachers thinking the theory and reality problems which are closely related to modern war. The teacher should strengthen the pertinence of teaching and develop the potential of teaching actively and practically. At the same time, the teacher should implement heuristic teaching ideas on the base of the efficiency and quantity, and supplant the old teaching mode of one-way traffic with the new modes of interactive, research, case studies, exercises and so on, and do their best to arouse and inspire the initiative and creative of the students researching issues. Construction of teacher staff also needs to train the teachers to love the army education, love and respect their jobs, and set a good moral demeanor. Training of the teachers for students is carried out not only through the imparting of knowledge, but also teachers own morals and manners, because the teachers' good ethics can have a subtle influence on students.

There is a problem cannot be ignored that how to rich the teachers actual troops work experience. It is very necessary for the teachers of military academy to be familiar with troop and its work rules, and only this way, the teacher could find and explore the problems of military construction. So that there will be live instances of troops in class, and the teaching and training can reflect substantial, novel ideas and timeliness ${ }^{[5]}$. The teacher should be systematically arranged to exercise in troops, and take advantage of the opportunity to familiarize the troop and research the troop, to improve the relevance and applicability of military teaching with the latest achievements in theoretical innovation, the latest academic perspectives, and the latest troop work practice,

The construction of teacher staff also needs to gradually implement the "military instructor system". The military instructor system is a serving education system adopted in most military academies of the world military powers today. This system can increase the pertinence, practice and frontier of the, and make the teaching close to the reality of troops. By means of working in military academy the military instructors can learn more knowledge to make their own theoretical level improved, at the same time, the problems that the military officers lack work experience of academy would be solved.

\section{CONCLUSION}

In the background of current military information warfare, there are new higher demands on military academy to train more and more talents with high military quality. It requires military Academy to keep up with the changes of combat capabilities generation mode, accelerate teaching reform, explore the way to train the students military quality under the condition of informatization, improve the quality of the class teaching and talent training. Around the teaching reform, four issues were discussed in this article, which are military curriculum system, teaching methods, construction of teaching materials and construction of teacher staff. This article is valuable for military academies in the teaching reform with the changes of combat capabilities generation mode.

\section{REFERENCES}

[1] Rong Zhao, Zou Peng, Bhattacharya. Military universities view of military courses structure optimization system and method [J]. Journal of higher education research,2003(4):74-76

[2] Dong Huiyu. Theoretical research on modernized teaching in military academies [M]. Beijing: the people's Liberation Army Publishing House,2005:252

[3] Shi Xiaoquan, Wu Qiang, pioneer. Teaching materials construction in professional education colleges to implement "six changes" [J]. Engineering academic,2007(2):23-24

[4] Zhu Ruke, Zhu Bin. New approach to the teaching of modern military [M]. Beijing: Ocean Press,2004:48

[5] Xue Liqun, Zhou Baowei. Characteristics of officer training, improve the capability of serving teachers [J]. Journal of professional training,2007(4):9-11 